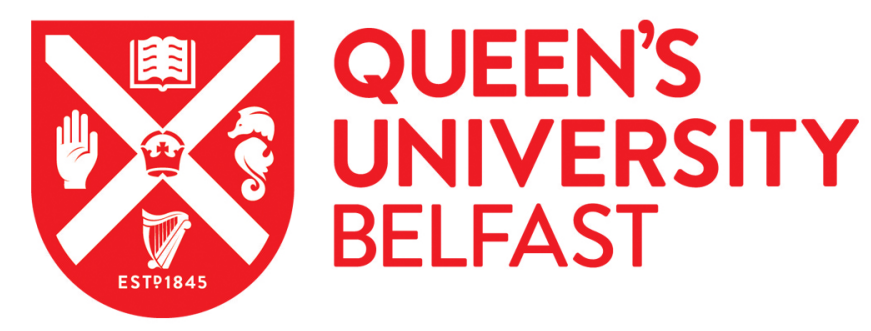

\title{
Peripatetic Philosophy: Sterne and Cosmopolitanism
}

Regan, S. (2017). Peripatetic Philosophy: Sterne and Cosmopolitanism. Textual Practice, 31(2), 265-282. https://doi.org/10.1080/0950236X.2016.1228846

\section{Published in:}

Textual Practice

\section{Document Version:}

Peer reviewed version

Queen's University Belfast - Research Portal:

Link to publication record in Queen's University Belfast Research Portal

\section{Publisher rights}

This is an Accepted Manuscript of an article published by Taylor \& Francis in Textual Practice on 02/11/2016, available online: http://www.tandfonline.com/doi/full/10.1080/0950236X.2016.1228846

\section{General rights}

Copyright for the publications made accessible via the Queen's University Belfast Research Portal is retained by the author(s) and / or other copyright owners and it is a condition of accessing these publications that users recognise and abide by the legal requirements associated with these rights.

Take down policy

The Research Portal is Queen's institutional repository that provides access to Queen's research output. Every effort has been made to ensure that content in the Research Portal does not infringe any person's rights, or applicable UK laws. If you discover content in the Research Portal that you believe breaches copyright or violates any law, please contact openaccess@qub.ac.uk. 
Peripatetic Philosophy: Sterne and Cosmopolitanism

A telling moment in the second volume of A Sentimental Journey (1768) sees a pensive Yorick struggling to envisage the condition of 'the millions of my fellow creatures born to no inheritance but slavery'. While the situation of these unfortunate beings might appear to offer an 'affecting' scene for sentimental reflection, Yorick finds ‘that I could not bring it near me, and that the multitude of sad groups in it did but distract me'. Moving quickly on, he directs his melancholic imagination instead to a 'single captive' imprisoned in a 'dungeon' - a figure who still exemplifies the 'miseries of confinement' but who bears little resemblance to the millions of slaves, presumably located in the Caribbean colonies, at whose plight Yorick had initially glanced. ${ }^{1}$

Sometimes read as typifying Sensibility’s troubled relationship to slavery, this illustration of the limitations to sympathetic engagement might also be read as a failure of cosmopolitan ethics. The difficulty Yorick experiences here is spatial as well as imaginative: the physical distance of this mass of suffering figures prevents Yorick from bringing them 'near' him, causing him to reach instead for the more immediate image of an incarcerated individual (someone akin, perhaps, to a prisoner in the Bastille, the particular source of Yorick's anxiety concerning his own liberty in this section of the narrative). This turning away from distress on a global scale has a contemporary correlative in Adam Smith’s The Theory of Moral Sentiments (1759). In a passage that was added to the second edition of the Theory (1761), Smith noted how easily even a 'man of humanity' in Europe would cease contemplating a 'dreadful calamity' that involved the 'great empire of China' being ‘suddenly swallowed up by an earthquake', notwithstanding the fact that the victims of this catastrophe would constitute an 'immense multitude', ‘a hundred millions' of the European’s ‘brethren'. While the moral agents envisaged 
by Smith would not actively forward such a disaster to prevent injury to themselves, they are nevertheless presented as 'sentimentally near-sighted', as Fonna Forman-Barzilai puts it, in relation to the lives of unknown others. ${ }^{2}$

For both Sterne and Smith, the objects of sentimental sympathy needed to be more familiar, as well as more particular, than such distant multitudes. Smith’s own concern here was with the Stoic notion of the "citizen of the world", an ideal he resisted as too severe in its call to collapse the concentric circles of one's life towards the centre, so as to feel for one's self and connections only as much as one felt for humanity at large. ${ }^{3}$ In its fleeting allusion to slavery, Sterne’s Journey signalled a similar reluctance to make grand claims for sympathy’s global reach, registering instead the tendency of moral feeling to privilege distresses closer to home. Yet although Yorick finds himself unable to stretch his sympathetic imagination as far as the West Indies, in other ways the Journey has much to say about cosmopolitanism as a crosscultural ethos. Here, I want to examine A Sentimental Journey as an essay in cosmopolitanism: as a work that engages, without necessarily endorsing, the idea of cosmopolitanism as, in the words of Jeremy Waldron, 'a way of being in the world, a way of constructing an identity for oneself that is different from ... the idea of belonging to or devotion to or immersion in a particular culture'. ${ }^{4}$ While it is not a "cosmopolitan text” in any straightforward or idealistic sense, I shall argue, Sterne's narrative can be read as a comic exploration of the idea, which tests the viability, and uncovers some of the ironies, of the attempt to adopt and inhabit a cosmopolitan identity.

Central to this reading is the work's status as a fictional travelogue. Sterne's narrative dramatises a tour through a nearby nation: in the Journey, it is the French who occupy the more proximate situation that distant millions do not. France's position in relation to Britain at this 
time is open to alternative emphases. On the one hand, as Robin Eagles reminds us, France was by no means a 'far-off and alien environment' for contemporary Britons, particularly as the Seven Years' War drew to a close and Continental tourism expanded (with Sterne himself being one of the first to take advantage). At the same time, it is also important to register what Katherine Turner terms the 'foreignness of Yorick’s experiences', the distinction between a 'sentimental' narrative set in France and one set in Britain. ${ }^{5}$ Viewed in a favourable light, what Yorick attempts through his travels is to engage sympathetically with the familiar strangers across the Channel, to take the French on their own terms and immerse himself in their way of life. This sentimental openness to alternative manners and customs constituted a reaction against the insular character of much contemporary discourse, not least in relation to France. In the narrative itself, such an attitude is represented by Tobias Smollett's Travels through France and Italy (1766), a work that, for all its learned curiosity, evidenced disdain for much that France had to offer, not least the manners of its people. ${ }^{6}$ Yorick’s travels, by contrast, would be conducted in more cosmopolitan style, in a mode of receptivity to French culture. From this perspective, Yorick resembles a 'cosmopolitan being' in the terms outlined by Zlatko Skrbiš and Ian Woodward: someone who is 'defined by an openness and willingness to change and indeed is open to being changed by encounters with difference'. ${ }^{7}$

The originality of Sterne’s narrative - the 'Novelty' of Yorick’s 'Vehicle' (p. 15) - was intimately connected to this accommodating outlook, which represented a departure not just from works such as Smollett's Travels but from the more overtly satiric aspects of Sterne's previous travel narrative, in volume 7 of Tristram Shandy (1765). At various points, this spirit of openness comes under strain as the reaction against Smollettian strictures falters and a cosmopolitan generosity of feeling proves hard to sustain. In his role as 'peripatetic philosopher' (a nice pun on the Aristotelian school), Yorick thus finds himself meditating upon the limits to, 
as well as the possibilities of, inter-cultural engagement and appreciation (p. 13). Periodically, he more specifically resembles an 'English philosopher’, as Madame de L*** terms him (p. 24): someone characterised not by openness to alterity but by bounded, nationally inflected attitudes. Such reversions to national type reveal the element of fantasy or wish-fulfilment in Yorick's sentimental cosmopolitanism, which cast a rosier hue over Sterne’s actual experience of France. 'Historically regarded', as Arthur Cash observes, Sterne exhibited 'a coolness toward French manners and a loyalty to English customs not at all suggestive of Yorick’s predisposition'. ${ }^{8}$ Yet, as this also implies, Yorick’s open 'predisposition' constituted a creative overwriting of Sterne’s growing disillusionment during his own travels. Aiming, as he put it, to 'teach us to love the world and our fellow creatures better than we do', Sterne here sought to re-conceive the encounter with the French. ${ }^{9}$ During his fictional journey, Yorick thus aspires to a mutual model of cosmopolitan engagement, of a kind that Kwame Anthony Appiah has characterised as 'conversation between people from different ways of life', or 'conversation across boundaries'. ${ }^{10}$ However faltering his pursuit of such conversational reciprocity, this sense of Yorick as conversable cosmopolitan offers a suggestive starting point by highlighting the distinctiveness of the Journey: a comic travelogue that would give a more outward-looking and sentimental turn to Sterne’s 'Shandean philosophy'. ${ }^{11}$

\footnotetext{
$* * *$

The possible benefits of contact with other nations are broached in a number of Sterne's writings. In his sermon 'The Prodigal Son', for instance, Sterne argued that it was the 'love of variety, or curiosity of seeing new things' - a passion or passions 'wove[n] into the frame of every son and daughter of Adam' - that instilled the human desire for travel. When approached correctly, the advantages of travel would include learning the languages, laws and customs of other nations, and acquiring 'an urbanity and confidence of behaviour' that would 'fit the mind
} 
more easily for conversation and discourse’. Even though, on the Grand Tour, bookish or indulgent governors might spoil their young charges, travel thus promised improvements to both the inner and the outer character through an experience of social interaction beyond that possible in any single country: 'by tasting perpetually the varieties of nature, to know what is good - by observing the address and arts of men, to conceive what is sincere,- -and by seeing the difference of so many various humours and manners,- - to look into ourselves and form our own'.12

Among other benefits, travel here represented a means for developing the refined behaviour and conversational ease appropriate to the social exercise of moral sincerity. This interest in the improvements to be accrued from travel is extended into A Sentimental Journey as Yorick endeavours to 'learn better manners' from his time with the French (p. 11). An ideal of inter-cultural respect is articulated towards the end of volume one, for instance, by the old French officer who Yorick meets at the opera comique in Paris. Having already demonstrated his own gentility of manners, the officer offers an international perspective on an insinuated 'grossierte' involving an Abbé and a couple of grisettes:

$[\mathrm{H}] \mathrm{e}$ had been in most countries, but never in one where he found not some delicacies, which others seemed to want. Le POUR, et le CONTRE se trouvent en chaque nation; there is a balance, said he, of good and bad every where; and nothing but the knowing it is so can emancipate one half of the world from the prepossessions which it holds against the other-that the advantage of travel, as it regarded the sçavoir vivre, was by seeing a great deal both of men and manners; it taught us mutual toleration; and mutual toleration, concluded he, making me a bow, taught us mutual love. (pp. 83-84) 
Noting the 'candour' and 'good sense' with which the officer delivers his speech, Yorick immediately affirms his own subscription to this cosmopolitan vision: '’twas my own way of thinking’ (p. 84). As envisaged here, 'mutual toleration’ emerges from a broad acceptance of the mixed nature of every society. The officer's words might thus appear to mediate nicely between two distinct attitudes to foreign cultures: between a universalising notion of ideal conduct that applies across nations, and a relativistic model in which the particular practices of any given nation are deemed appropriate to that nation. In other ways, though, the officer's speech reveals the incompatibility of these different conceptions. As we might ask, for instance: if there is 'good' and 'bad' everywhere, by what criteria are the 'good' and the 'bad' being judged? An answer may lie in the officer's reference to admirable 'delicacies', which hints at a behavioural gold standard that he does not fully articulate. This standard, which seems to exist beyond any particular (national) perspective, is that of what he terms the 'sçavoir vivre' (savoir-vivre), which can be glossed as knowledge of the world but also, more specifically, as elegant living. It is from the perspective of this refined yardstick that the delicacies to which the officer refers will appear as 'delicacies'. The ideal of cosmopolitan toleration that the officer sketches, we might then say, presumes the worldly sophistication it seeks to promote.

As even this brief analysis might suggest, one of the central difficulties when addressing cosmopolitanism is the often circular, contradictory or inchoate nature of the concept. In a recent discussion of the eighteenth century's place within the 'new cosmopolitanism' of the last 15-20 years, Mary Helen McMurran has emphasised the 'incoherent' nature of cosmopolitanism during the period itself. In McMurran’s view, there was 'little philosophical inquiry of the subject' during the eighteenth century, and what discussions there were treated the idea with scepticism. ${ }^{13}$ Few writers, certainly, wholly endorsed the "concentric” model of worldcitizenship, which involved adopting a ‘stoical apathy', as Smith would put it, to one’s nearest 
and dearest. ${ }^{14}$ Nevertheless, as the passages above from 'The Prodigal Son' and A Sentimental Journey also indicate, broader ideas about cosmopolitan toleration, education, and improvement were often rehearsed at this time in travel narratives and in other discourses on the purposes of travel.

A pertinent case in point here is a work published a few years before the Journey: Richard Hurd's Dialogues on the Uses of Foreign Travel (1764). This was not a work of philosophy as such, but one that reanimated two well-known philosophers, John Locke and the third Earl of Shaftesbury, for a "dialogue of the dead" on the role of travel in an 'English Gentleman's Education'. ${ }^{15}$ A summary of the two speakers' arguments can help to establish the terms of Sterne’s more intricate approach in the Journey. During their discussion, 'Shaftesbury' presents an adapted version of the Stoic ideal that involves enlarging the circle of one's life outward, from the local to the national to the international. For Shaftesbury, this process leads to greater tolerance: 'as their views enlarge', he contends, young gentlemen will be 'enabled to shake off their local, as we may say, and territorial prejudices'. Revealingly, this fictional Shaftesbury invokes an image of polite polishing that the historical Shaftesbury had himself used in Sensus Communis (1709), and that Sterne would also utilise in A Sentimental Journey. By a 'near approach and attrition’ between persons, he suggests, 'our rude parts give way; our rough corners are insensibly worn off; and we are polished by degrees into a general and universal humanity’. ${ }^{16}$ Strikingly, Hurd here extended Shaftesbury’s own image for sociable interaction what he had termed 'a sort of amicable collision' - to the experience, and the civilising function, of foreign travel; adding a Continental resonance to the process described in Sensus Communis itself. ${ }^{17}$ Against this refining conception, Hurd's Locke emphasises the absorptive dangers of travel, the risk of contracting foreign vices (what he terms an 'infection'). Here, Shaftesbury's vision of a 'Citizen of the world' is contrasted to the more desirable ideal of a 'worthy citizen of 
England'. Invoking John Locke’s own theory of the association of ideas, 'Locke' asks, somewhat pointedly: 'What if the ideas of Liberty chanced to be closely connected with those of Old England'. While he is not 'wholly bent against the practice of foreign Travel', then, this fictional Locke believes, as did the philosopher himself, that such travel is not 'the most proper method of a young gentleman's education'; that it will furnish such gentlemen only with 'shewy and ornamental accomplishments'. ${ }^{18}$

Hurd's philosophical dialogue is not, certainly, dialogic in the Bakhtinian sense. Even though the entire work supposedly represents Shaftesbury's recollection of a conversation with Locke in the company of friends during the later seventeenth century, Locke's suspicions about the benefits of European travel to young English aristocrats tend to win the day (if only by dint of filling the text's second half), and Shaftesbury's enthusiasm for the educative efficacy of such journeys is made to appear naive. ${ }^{19}$ Nevertheless, Hurd's work usefully delineates the conceptual parameters of Yorick's own journey through France. In his 'preface', on the one hand, Yorick expresses scepticism about the 'knowledge' and 'improvements' to be gained by travel (p. 16). In words that align him with Hurd's Locke, Yorick here describes a situation of cultural particularity in which nation-specific ‘education, customs and habits' render inter-cultural communication almost a 'total impossibility', leaving the 'expatriated adventurer' continually undersold (p. 13). Yet elsewhere, pace ‘Shaftesbury’, it appears that self-improvement through sociable commerce abroad may well be possible. The transformative potential of cross-cultural conversation is suggested, for instance, by Yorick’s encounter with the monk, Father Lorenzo. Having initially insulted the Father, Yorick is later reconciled with him through a sentimental exchange of snuff-boxes. As the description of Yorick's own snuff-box as a 'peace-offering' (p. 26) conveys, this successful moment of everyday cosmopolitan interaction is offered up in the narrative as a miniature allegory of inter-national amity. 
Yorick might be regarded, then, as fluctuating between the positions taken by 'Locke' and 'Shaftesbury' in Hurd's Dialogues. As this shifting viewpoint implies, one of the lessons of Yorick’s peripatetic attempt to improve his manners is that maintaining an amicable openness, and overcoming 'local' and 'territorial' prejudices, is no simple task. The difficulty of achieving a cosmopolitan generosity of outlook is hinted in the Journey's opening chapter. In this chapter, Yorick's account of his excursion across the Channel quickly becomes a flight of imagination in which the English traveller ends up criticising the French king for having seized his belongings (following Yorick’s projected death), before coming back to his senses and recalling that he has, in fact, barely arrived at Calais. To Yorick here, the French are 'a people so civilized and courteous, and so renown'd for sentiment and fine feelings' (p. 4): a generous assessment which, to all appearances, validated the nation's preferred self-image. This open attitude comprised a specific reaction to Smollett's Travels. Defining politeness as the 'art of making one's self agreeable', Smollett had observed that this art necessarily implied 'a sense of decorum, and a delicacy of sentiment' - qualities, he contended, that a Frenchman had 'no idea' of. Smollett's ire had been immediately raised in France by the confiscation of his books, which had led him to attack the 'tyranny' of the droit d'aubaine, the law whereby (as he put it) 'if a foreigner dies in France, the king seizes all his effects'. ${ }^{20}$ At one level, Yorick’s account of his own arrival in France represents a parodic subversion of Smollett's barbs against the impoliteness and bureaucratic inhospitality of the French. Yet there is also a sense in which Smollett's concerns inform Yorick's response to his own expatriation. While he praises the French for their civility, Yorick also reaffirms what Smollett had been so keen to register: that this national claim to politeness was incompatible with the practical impositions of French law. As his reaction to his arrival at Calais suggests, simply to enter France might entail, for an eighteenth-century English Protestant, a state of anxiety about foreign threats to both his life and his property. Even as he 
sits down to taste French culture in a fricasseed chicken, Yorick is unable to suppress the reflex consideration that doing so might well bring on a fatal case of indigestion. Before recalling that he has 'scarce set foot' in France, Sterne’s cosmopolitan traveller thus finds himself echoing Smollett, indulging in an anxious reverie about the pillage of his own possessions under the oppressive operation of the droit d'aubaine (p. 4).

In his opening salvo against Smollett, then, Sterne ridiculed, but also restaged, Smollett’s critique of French claims to politeness. One way of reading this would be to say that Yorick's cosmopolitan predisposition is placed under suspicion from the very outset. In his correspondence, Sterne had bitterly recorded his own tussle with the 'Villany \& extortion’ of the droit d'aubaine. ${ }^{21}$ Yet the opening of the Journey is far less straightforward than the epistolary account, and suggests rather the constitutive ambiguity of Sterne's fictional examination of cosmopolitan travel. Yorick's narrative, I would argue, operates on two interconnected levels. In order to free himself from the mental shackles of national partiality, Sterne's narrator both ventriloquises the positive self-evaluation of the French and endeavours to do as the French do. As he flatters French claims to social refinement and attempts to ingratiate himself into this cultivated milieu, however, the narrative also exposes the disjunction between Yorick's generous predisposition and what could easily appear, from an English perspective, to be problematic, and specifically French, forms of social behaviour. An important aspect of this process concerns conversation between the sexes. Early in the narrative, Yorick offers an ironic reflection on the 'good breeding' of a 'little French debonaire captain’ who badgers Madame de L*** with questions before describing to her the bombardment of her home town of Brussels (pp. 30-31). As his reflection indicates, Yorick is well aware that the easy manners of the French were no guarantee of decorous commerce between the sexes. At other times, though, Yorick's own interactions with women are equally implicated in French modes of social behaviour. In a scene 
that hints at the insincerity (and the dubious morality) of French gallantry, for instance, Yorick sends Madame de $\mathrm{L}^{* * *}$ an adapted version of a billet doux that was originally written to a corporal's wife by a French drummer (pp. 63-64). ${ }^{22}$ Indeed, during the course of the Journey, Yorick’s cosmopolitan impulses are themselves shown to have an amorous charge. Just as he alludes to Shaftesbury's image of 'amicable collisions' during a tactile encounter with a Parisian grisette, so his apparently cosmopolitan assertion, 'are we not all relations?', is voiced as he links arms with a young fille de chambre in the street (pp. 73, 90). That Yorick's own vision of global travel is propelled by his attachment to his latest Dulcinea is conveyed even more directly early on in the narrative when, in relation to Madame de $\mathrm{L}^{* * *}$, he exclaims 'Good God! how a man might lead such a creature as this round the world with him!- ${ }^{\prime}$ (p. 22). ${ }^{23}$

Yorick’s dealings with women thus connote both the morally suspect nature of the French forms of gallantry he mimics and the sensual undercurrent to his pursuit of cosmopolitan conversation. Such “conversation” (or what, elsewhere, he terms a 'connection') necessarily creates a suspicion that, rather than divining the 'pour' and the 'contre' in each situation, Yorick is (so to speak) cherry-picking the valuable aspects of Continental culture according to his own desires and (self-) interests. During the course of his journey, moreover, Yorick finds his idealised conception of the French national character itself being placed under stress. The presumptions about French politeness that had informed his response to the droit d'aubaine are displayed again, for instance, at the opera comique, as he responds to the insinuated 'grossierte' regarding the Abbé and the grisettes with an expression of refined shock: 'Good God! said I, turning pale with astonishment—is it possible, that a people so smit with sentiment should at the same time be so unclean, and so unlike themselves' (p. 83). In contrast to Smollett’s dogged refusal to allow 'delicacy of sentiment' to the French, Yorick here reasserts his belief that it is only by displaying the fine feelings for which they were renowned that the French would act in a 
manner truly self-identical (or, be like themselves). Yet, as the word 'smit' also suggests, Yorick’s response to the audience's freedom with the Abbé positions the French as captivated by, but as not sufficiently possessed of, refined sentiment. As this corrosion of his generous preconceptions about French delicacy indicates, Yorick’s predetermination to be open and to adapt to his hosts’ culture runs into various difficulties during his travels. Matters are not helped in this particular instance by the fact that Yorick's discussion with the old French officer is immediately succeeded by an account of his dealings with Madame de Rambouliet. In a moment that demonstrates his partial interpretation of the officer's speech on 'mutual toleration', Yorick is here shown becoming naturalised to a situation - a French woman's willingness to relieve herself in the presence of a man - that had outraged Smollett and that was unlikely to strike most readers in Britain as conforming to any acceptable standard of civilised behaviour (p. 84). ${ }^{24}$

In his interactions with women, Yorick veers towards a relativistic approach to cultural difference, embracing the alternative behavioural standards of the French at his (and the lady's) convenience. Elsewhere in the work, Sterne's traveller insists instead on the universal(ising) model, according to which general standards of conduct were applicable across nations. Central to this aspect of the Journey is the cosmopolitan requirement of hospitality to strangers. This would receive its most famous articulation later in the century in the writings of Kant. As he defined it in Perpetual Peace (1795), hospitality for Kant meant 'the right of a stranger not to be treated with hostility when he arrives on someone else's territory'. In Kant's view, such strangers could claim only 'the right of resort' in a foreign territory, not 'the right of a guest to be entertained' ${ }^{25}$ Earlier in the century, other writers had tied the cosmopolitan desideratum of hospitality more specifically to the obligations upon hosts under the banner of politeness. In David Hume’s formulation of the ideal, for instance, 'Strangers and foreigners are without 
protection: Hence, in all polite countries, they receive the highest civilities, and are entitled to the first place in every company'. ${ }^{26}$ As Hume’s formulation implies, civility to foreigners (and other unknown guests) could be regarded as a litmus-test for any claim to national politeness. ${ }^{27}$ This duty of hospitality, or protection of strangers, formed an important element within the English-French contention over manners and morals. As the Abbé Le Blanc indicated of his countrymen in 1747: 'WE hold politeness to strangers to be one of the virtues of our nation; yet 'tis one of those which the English dispute the most with us'. ${ }^{28}$ With a certain irony, their competing claims to polite hospitality fed into the inter-national rivalry between England and France during this period.

The opening chapter of A Sentimental Journey, which I considered earlier, is centrally concerned with this disputed virtue of politeness to strangers. Reflecting on the droit d'aubaine, Smollett had averred that he knew of 'no country in which strangers are worse treated, with respect to their essential concerns', than they were in France. ${ }^{29}$ In his anxious reverie about the same law, Yorick himself invokes this notion of French national inhospitality. Having appeared to embark for France in a fit of spontaneity, he now chides his hosts for piratically seizing 'upon the wreck of an unwary passenger, whom your subjects had beckon'd to their coast'. That the visitor is an invalid - a 'wreck' - only compounds their apparent failure of civility (p. 3). This trope of Yorick as defenceless traveller, at the mercy of his hosts' humanity, recurs at various points in the Journey. Yorick is referred to as a 'stranger', for instance, in successive chapters in volume one: firstly by the Parisian grisette, who defends the integrity of her dealings with him, and subsequently in Yorick’s translation of the old French officer's gestural welcome to him: ““Here’s a poor stranger ...”' (pp. 75-76). This ‘translation’ is as much a projection of Yorick’s sense of himself, as someone in need of protection, as it is an account of the officer's mental processes. Yet this sense of Yorick's vulnerability intensifies later in the narrative, following his 
recollection that France and Britain are still 'at war' and his realisation that the 'terror' of the Bastille does not, after all, consist merely in the word itself (pp. 91, 94). Seeking an audience with the Duc de C***** [Choiseul] in order to procure a passport, Yorick again casts himself as 'an absolute stranger' in France - 'and what is worse in the present conjuncture of affairs, ... an Englishman too' (p. 102). Passports, as well as allowing for inter-national mobility, bind their possessors to particular nation-states, defining them as "nationals" rather than citizens of a broader community. As his susceptibility to the operation of French law becomes more tangible and his need for a passport more pressing, Yorick becomes more aware of his own national status, and more concerned to impress upon his hosts a cosmopolitan obligation of hospitality that, in theory at least, superseded particular national interests.

As Carol Kay observes, Yorick's fear of the Bastille, 'Sterne’s best sop to the anti-French prejudices of the English', reveals 'the limits of sentimental fantasy'. ${ }^{30}$ It also indicates the pressure that his pursuit of a passport places upon his cosmopolitan openness. The entwined issues of national identity, cosmopolitan generosity, and hospitality to strangers come to a head during Yorick’s interview with the Count de B***. Despite his mixed experience of French manners by this point, Yorick again reverts here to the paradigm of politeness as a French national characteristic: the French are ‘the most polish'd people in the world'. Their defining 'gallantry', he suggests, makes it unnecessary for the French to engage in any special exercise of 'mercy’ where 'invalids' such as Yorick are concerned (p. 109). This appeal to the Count reveals more clearly what had remained latent in Yorick’s earlier paeans to French civility: the potentially self-serving character of a cosmopolitan disposition. The purpose of Yorick’s national praise during this meeting is to make it more difficult for the Count to refuse his request for assistance in procuring a passport. In effect, Yorick manoeuvres the Count into a position in which any refusal to help such a defenceless stranger would undermine the very picture he has 
just drawn of his nation's virtues. As he praises French politeness and hospitality in order to gain his papers, Yorick thus exposes the element of strategy within his own adoption of a polite cosmopolitan identity.

The combined strain of his legal vulnerability and his (un)cosmopolitan manoeuvring during this meeting begins to tell as Yorick finally voices the reservations that have emerged in his opinion of his hosts. Asked whether he has discovered 'all the urbanity in the French which the world give us the honour of', Yorick replies that the French are indeed polished, but to an 'excess’ (p. 118). When the Count insists that he elaborates on this slight against the French national self-image, Yorick is coaxed into a more formal statement of his views on the distinction between the English and the French, with regard to social refinement:

[S]hould it ever be the case of the English, in the progress of their refinements, to arrive at the same polish which distinguishes the French, if we did not lose the politesse de cœur, which inclines men more to humane actions, than courteous ones—we should at least lose that distinct variety and originality of character, which distinguishes them, not only from each other, but from all the world besides. (p. 119)

Here, the English possess a defining quality, 'variety and originality of character', that distinguishes them from 'all the world': a patriotic contention that appears difficult to reconcile with a supra-national cosmopolitanism or a willingness to change through encounters with difference. Continuing his statement, Yorick proceeds to qualify his earlier, Shaftesburian account of the refining agency of 'social intercourse' (with its 'amicable collisions') by comparing the English to 'antient medals': un-commercial units which, less subject to social circulation than coins, retain more of their original characteristics (pp. 73, 119). Pointedly, as 
Kay notes, the coins Yorick selects to illustrate the polish of the French themselves are King William shillings, 'English coins that have rubbed up against one another so much that they have worn away the features of the defender of English liberty'. ${ }^{31}$ The constitutional liberty that risks being erased here was the very condition of the 'variety and originality of character' that Yorick has just been defending. For Yorick, as for 'Locke' in Hurd's Dialogues, this notion of 'Liberty' is intimately associated with the idea of 'Old England'. Particularly within the context of war in which (with deliberate anachronism) the Journey is set, there could be no question of regarding such liberty as merely one 'pour' in favour of England, against which might be balanced a corresponding list of positive facets of French culture. ${ }^{32}$

Rather than merely observing the differences between the national characters of England and France, then, Yorick chooses in this interview to defend the angular English against the polished refinements associated with the French, sanctioning not a tolerant cosmopolitanism but a national hierarchy constructed upon cultural differences. The tenor of this encounter is not, perhaps, entirely surprising. Tanya Agathocleous has noted the predictability with which literary texts, when analysed for their content, tend to reveal the 'limitations and failures' of cosmopolitanism. ${ }^{33}$ More specifically, as Katherine Turner observes, during the period 1750 1800 'few if any travel narratives fail, in the final analysis, to prefer Britain to the Continent' ${ }^{34}$ Yet Yorick’s reversion to national sentiment during his meeting with the Count de $\mathrm{B}^{* * *}$ is not quite the end of the story of cosmopolitanism in A Sentimental Journey. Although Sterne’s peripatetic philosopher ultimately concurs with other contemporary commentators in viewing the polished manners of the French as homogenising mannerisms, the terms of this critique also involved appropriating, for the English, modes of French culture that were more congenial to their own sense of national self-identity. Against the performative model of politesse, with which he later experiments in the Parisian salons, for example, Yorick here defends, as 
characteristic of the English, a more inner or virtue-led politeness: a 'politesse de cœur'. That he is doing something more here than simply polarising English polite virtue and French social courtesies is indicated by Peter France’s discussion of new conceptions of virtuous politeness that were put forward in France itself during the eighteenth century. As France suggests, while they did not necessarily constitute a unified project or agree upon a single, distinct formulation of new kinds of polite behaviour, these views 'challenged the court-centred politesse with its stress on polished manners, and tried to envisage a more inward politeness ("la politesse du cœur”), and one that was more appropriate to free relations between equals - a politeness for the polis'. ${ }^{35}$ In his appeal to this humane 'politesse de cour', then, Yorick was participating in an attempt more closely to harmonise manners and morals that was already being made by the French themselves.

With what might be regarded as an audacious piece of cultural hijacking, Sterne's text relocated this (French) conception of 'inward politeness' to the modern English. This is not, of course, quite the same thing as simply being open to alternative ways of life, the supposed principle of a cosmopolitan identity. As Skrbiš and Woodward counsel, while such openness is an 'epistemological principle of cosmopolitanism', in some cases it may involve instead 'a form of cultural appropriation'. ${ }^{36}$ And yet, such appropriative behaviour can also be viewed as one effect of cosmopolitan openness, as distinct from a straightforward rejection of (national) difference. While the French are undoubtedly found to be lacking in certain respects in the Journey - not least for what Sterne himself termed their samey 'civility' - Yorick is nonetheless willing to adopt from them the finer 'delicacies' that England, with its reputation for spleen and un-complaisant insolence, could still appear to lack. ${ }^{37}$ Nor is this appropriative process the only way in which cosmopolitanism remains relevant to the Journey. Importantly, during the remainder of the narrative, Yorick displays a continuing willingness to engage. His experiences 
in the chapters 'The Supper' and 'The Grace', for instance, are suggestive of a more natural cosmopolitanism, in terms of both the rural hospitality he receives and his own joyous response to rustic innocence. The pastoral simplicity of these moments can only be temporary for such an urbane traveller, and the Journey's final chapter, 'The Case of Delicacy', returns him to his more habitual environment of coaches and lodgings, self-consciousness and moral uncertainty. ${ }^{38}$ Characteristically, the 'treaty of peace' that Yorick makes here falters, and the work threatens to end in 'hostilities' (pp. 163, 165). Yet the novel's finale foregrounds the necessary condition of cosmopolitanism, the inevitability of interacting and negotiating with other people in foreign settings. Grappling with the apparently impossible situation of sharing a room with a lady and her maid-servant, Yorick thus finds himself back in a familiar habitat, in which travel is shown to be a sphere of contentions and reconciliations, peace-offerings and acrimonies, and the play of sexual association itself provides a textual trope for a more worldly sociality.

The (in)delicate denouement of A Sentimental Journey involves a comedy of embarrassment and miscommunication, negotiations and mixed motivations, that registers the everyday experience of the expatriated adventurer. This might be regarded as the particular value of Sterne's fictional travelogue with regard to cosmopolitanism. Cast in part as a response to Smollett's Travels, Sterne’s text did not comprise an equal and opposite reaction. At one level, the riposte to Smollett opened up the possibility of envisioning a more cosmopolitan approach to foreign cultures, specifically that of the old enemy across the water. As Yorick’s attempt to resist Gallophobia and to learn from the French suggests, the Journey cannot be recruited wholesale to a contemporary, British middling-class reaction against what was increasingly perceived to be (as Turner puts it) 'the unpatriotic cosmopolitanism of the aristocracy'. ${ }^{39}$ Yet Yorick's stab at sympathetic openness is itself shown to be impeded by latent structures of thinking, partiality of 
engagement, and the inevitable complexities of inter-cultural "conversation”. What emerges from this cosmopolitan enterprise is, then, a variegated picture rather than a coherent schema. Unlike Walter Shandy, Yorick is not a 'systematick' thinker; the Journey, as he notes, is 'not a work of reasoning' (p. 80). ${ }^{40}$ Yorick’s cosmopolitanism is both interested and erratic. As his early perception of the 'rights' to be gained by Continental travel implies (p. 3), Yorick seeks to profit from his peregrinations, to acquire the cultural capital that his openness to the French might convey. His declarations of cosmopolitan intent can themselves be self-regarding, even bathetic. Back again in Calais, for instance, it is his consumption of Burgundy wine that leaves him 'at peace' with the world and in a fine cosmopolitan disposition, 'more warm and friendly to man' (p. 5). And yet, however compromised, limited or temporary his implementation of cosmopolitan aims and ideals, it is the very invocation of these principles that marks the particular complexion of Yorick’s travels.

Sterne’s trick in the Journey, we might say, was to turn English suspicions of Continental travel to comedy, rather than complaint. The novel's textured and (at times) vacillating approach offers an instructive angle on modern cosmopolitanism studies, with its sometimes bifurcated vision, split between idealism and scepticism. Sterne’s text plays out in interesting ways a tension, between wary patriotism and a more outward-looking perspective, that has been central to this field since its beginnings in the mid-1990s, following the publication of Martha Nussbaum's 'Patriotism and Cosmopolitanism' (1994) and the debate it provoked. ${ }^{41}$ As Yorick’s peripatetic experience evidences, the two elements within Kwame Appiah’s suggestive formulation, ‘cosmopolitan patriotism', are ever in a state of complex interplay. ${ }^{42}$ Yorick’s journey incorporates an intricate reminder that, rather than representing an abstract ideal, cosmopolitanism necessarily involves interactions with others; that, even when conceived as a ‘lived category’ or as ‘actually existing cosmopolitanism’ (to cite an often-quoted formulation), 
such interactions are rarely pure demonstrations of kind-hearted openness, 'mutual toleration’ or 'mutual love'. ${ }^{43}$ And yet, as the Journey also attests, neither is this merely 'a hostile kind of a world' (p. 20) in which reconciling differences beyond one's national shores constitutes a total impossibility. Rather than a polarised picture of either engagement or insularity, the Journey offers its readers a sophisticated exploration of cosmopolitanism and its discontents, a comic rendering of both the potential for, and the difficulty of realising, an open-minded, otherregarding identity.

In her discussion of Adam Smith and cosmopolitanism, Fonna Forman-Barzilai asks: 'what might it mean ... to extend his well-known ideas of "sympathy" and "spectatorship" to distant strangers?' ${ }^{44}$ In A Sentimental Journey, I have argued, Sterne explored what it might mean to extend sympathy to strangers closer to home; to a people who, for some commentators at this time, were not too distant for sympathy but, rather, too close for comfort. During the Journey, Yorick exercises his sympathetic imagination within this foreign setting, so that the physical distance that had seemed, to Smith, to hinder global sympathy is removed (as though Smith's 'man of humanity’ had actually travelled to China to condole its distressed people at close quarters). Yet the very act of roaming abroad also introduced a further element to the picture: the host country's cosmopolitan exercise of hospitality to strangers. In a fictional engagement that looks two ways, Yorick's travelogue thus presents a comedy of cross-cultural purposes which tests both his own ability to sustain a generous attitude to national others and, through this, his hosts' willingness to receive him with the 'highest civilities' of cosmopolitan openness.

\footnotetext{
${ }^{1}$ Laurence Sterne, 'A Sentimental Journey through France and Italy' and 'Continuation of the Bramine's Journal': The Text and Notes, ed. Melvyn New and W.G. Day, vol. 6 of The Florida Edition of the Works of Laurence Sterne (Gainesville: University Press of Florida, 2002), p. 97.
} 
Further references will be given parenthetically.

${ }^{2}$ Adam Smith, The Theory of Moral Sentiments, ed. D.D. Raphael and A.L. Macfie (Oxford: Clarendon Press, 1976), p. 136; Fonna Forman-Barzilai, Adam Smith and the Circles of Sympathy: Cosmopolitanism and Moral Theory (Cambridge: Cambridge UP, 2010), pp. 50-51.

${ }^{3}$ In this regard, Forman-Barzilai argues, Smith was 'distinctively anti-cosmopolitan': 'Smith refused to follow the Stoic argument to its cosmopolitan conclusion that rational agents must cultivate "apathy" toward the near and dear, learn to resist oikeiosis (the natural affection born of familiarity), to collapse the circles, and become "citizens of the world"' (Adam Smith and the Circles of Sympathy, p. 8).

${ }^{4}$ Jeremy Waldron, 'What is Cosmopolitan?' (1999), in The Cosmopolitanism Reader, ed. Garrett Wallace Brown and David Held (Cambridge: Polity Press, 2010), pp. 163-75 (p. 163). ${ }^{5}$ Robin Eagles, Francophilia in English Society, 1748-1815 (Houndmills, Basingstoke: Macmillan, 2000) p. 123; Katherine Turner, British Travel Writers in Europe, 1750-1800: Authorship, Gender and National Identity (Aldershot: Ashgate, 2001), p. 88.

${ }^{6}$ For a defence of Smollett that highlights his active engagement with foreign cultures, see Ian Campbell Ross, 'When Smelfungus met Yorick: Tobias Smollett and Laurence Sterne in the South of France, 1763', in Tobias Smollett, Scotland's First Novelist: New Essays in Memory of Paul-Gabriel Boucé, ed. O.M. Brack, Jr. (Newark: University of Delaware Press, 2007), pp. 7493.

${ }^{7}$ Zlatko Skrbiš and Ian Woodward, Cosmopolitanism: Uses of the Idea (London: Sage, 2013), p. 10.

${ }^{8}$ Arthur H. Cash, Sterne's Comedy of Moral Sentiments: The Ethical Dimension of the 'Journey' (Pittsburgh, PA: Duquesne UP, 1966), p. 50.

${ }^{9}$ Sterne to Anne James, 12 November 1767, in The Letters, ed. Melvyn New and Peter de Voogd, vols. 7-8 of The Florida Edition of the Works of Laurence Sterne (Gainesville: University Press of Florida, 2009), VIII, 629.

${ }^{10}$ Kwame Anthony Appiah, Cosmopolitanism: Ethics in a World of Strangers (London: Penguin, 2006), pp. xix, 72.

${ }^{11}$ Sterne to Robert Foley, 16 November 1764, in Letters, VII, 399.

12 The Sermons of Laurence Sterne, ed. Melvyn New, vols. 4-5 of The Florida Edition of the Works of Laurence Sterne (Gainesville: University Press of Florida, 1996), IV, 192 (Sermon 20). ${ }^{13}$ Mary Helen McMurran, 'The New Cosmopolitanism and the Eighteenth Century', Eighteenthcentury Studies, 47:1 (Fall 2013), 19-38 (pp. 28, 22). A contrasting (if broader-brush) picture is provided by Thomas J. Schlereth, The Cosmopolitan Ideal in Enlightenment Thought: Its Form and Function in the Ideas of Franklin, Hume, and Voltaire, 1694-1790 (Notre Dame: University of Notre Dame Press, 1977). Quoting Diderot's definition of the 'cosmopolite' in the Encyclopédie, for instance, Schlereth notes 'the common Enlightenment assumption that eighteenth-century philosophe[r]s were synonymously and simultaneously cosmopolites’ (p. 47). ${ }^{14}$ Smith, Theory of Moral Sentiments, p. 143 (from the sixth edition of the Theory, published in 1790).

${ }^{15}$ Richard Hurd, Dialogues on the Uses of Foreign Travel; Considered as a Part of an English Gentleman's Education: Between Lord Shaftesbury and Mr. Locke (London, 1764). While the two philosophers are not fully fleshed out in the work, they were not selected entirely at random. Locke appears here as the author of Some Thoughts Concerning Education (1693), Shaftesbury for his use of the dialogue form in Characteristicks (1711) and, more broadly, for his association with politeness. Although Hurd's revivification of these dead thinkers might appear historically backward-looking, the terms of their dialogue situate his text firmly within the mid-eighteenthcentury discourse about refinement and luxury: whereas Shaftesbury regards travel as having enabled 'the national improvement in arts and civility', for instance, this benefit is overridden, in 
Locke's view, by the 'degeneracy' in 'our principles and our morals' that this had entailed (p. 20).

${ }^{16}$ Hurd, Dialogues, pp. 32-33.

${ }^{17}$ See Anthony Ashley Cooper, third Earl of Shaftesbury, 'Sensus communis, an essay on the freedom of wit and humour in a letter to a friend', in Characteristics of Men, Manners, Opinions, Times, ed. Lawrence E. Klein (Cambridge: CUP, 1999), pp. 29-69 (p. 31).

${ }^{18}$ Hurd, Dialogues, pp. 23, 74, 96, 150-51, 91. For Locke's own discussion of travel and the problem of the age at which gentlemen typically conducted the Grand Tour, see 'Some Thoughts Concerning Education' and 'On the Conduct of the Understanding', ed. Ruth W. Grant and Nathan Tarcov (Indianapolis: Hackett Publishing Company, 1996), pp. 158-61.

${ }^{19}$ In this, as Michèle Cohen argues, the Dialogues reflected growing sentiment against 'the very notion of travel as a means of fashioning the gentleman'. See Fashioning Masculinity: National Identity and Language in the Eighteenth Century (London: Routledge, 1996), p. 60.

${ }^{20}$ Tobias Smollett, Travels Through France and Italy, ed. Frank Felsenstein (Oxford: Oxford UP, 1979), pp. 57, 9.

${ }^{21}$ Sterne to John Mill, 5 March 1763, in Letters, VII, 311.

${ }^{22}$ In the marginal annotations to his copy of the Journey, John Scott, Earl of Clonmell (17391798) observed that the easy adaptability of this letter demonstrated ' $y$ e Ridiculous sameness \& Affectation of $y^{\mathrm{e}}$ French Nation'. See Paul Franssen, “'Great Lessons of Political Instruction”: The Earl of Clonmell Reads Sterne’, The Shandean, 2 (1990), 152-201 (p. 173).

${ }^{23}$ Compare Sterne's account of his own 'sentimental' (and Frenchified) affections in a letter to John Wodehouse of 23 August 1765: 'I myself must ever have some dulcinea in my head-it harmonises the soul-and in those cases I first endeavour to make the lady believe so, or rather I begin first to make myself believe that I am in love-but I carry on my affairs quite in the French way, sentimentally' (Letters, VIII, 449-50).

${ }^{24}$ Smollett, Travels, pp. 33-34. Smollett had described this practice in support of his contention that 'nothing can be more absurd, than to plead the difference of custom in different countries, in defence of those usages which cannot fail of giving disgust to the organs and senses of all mankind' (p. 33).

${ }^{25}$ Immanuel Kant, 'Perpetual Peace: A Philosophical Sketch', in Kant's Political Writings, ed. Hans Reiss, trans. H.B. Nisbet (Cambridge: Cambridge UP, 1970), pp. 93-130 (pp. 105-106). As Kant emphasises, his discussion of hospitality is concerned 'not with philanthropy, but with right' (p. 105).

${ }^{26}$ David Hume, 'Of the Rise and Progress of the Arts and Sciences', in Essays Moral, Political, and Literary, ed. Eugene F. Miller (Indianapolis: Liberty Fund, 1985; rev. ed., 1987), pp. 111-37 (p. 132).

${ }^{27}$ As Johnson's Dictionary put it, a 'stranger' could mean a 'foreigner; one of another country', 'one unknown', and 'a guest' (Samuel Johnson, A Dictionary of the English Language, 2 vols [London, 1755], II, n.p.).

${ }^{28}$ Jean Bernard Le Blanc, Letters on the English and French Nations, trans., 2 vols (London, 1747), I, 22.

${ }^{29}$ Smollett, Travels, p. 9.

${ }^{30}$ Carol Kay, Political Constructions: Defoe, Richardson, and Sterne in Relation to Hobbes, Hume, and Burke (Ithaca: Cornell UP, 1988), p. 261.

${ }^{31}$ Kay, Political Constructions, p. 263.

32 This anachronistic setting, which partly reflects Sterne's recollection of his trip to the Continent in 1762, has various implications in the Journey. The context of war, for example, exacerbates Yorick's need for a passport; as Eagles notes, formal travel papers were not normally required before 1770, and then only for movement onwards or to return to England 
(Francophilia, pp. 97, 123). As Eagles also indicates, except in time of war the English were also exempted from the operation of the droit d'aubaine (by the Treaty of Utrecht), though it appears that this was not always fully appreciated (p. 108).

33 Tanya Agathocleous, 'Cosmopolitanism and Literary Form', Literature Compass, 7:6 (2010), 452-66 (p. 453).

${ }^{34}$ Turner, British Travel Writers, p. 10. See also Jeremy Black, The British Abroad: The Grand Tour in the Eighteenth Century (Stroud: Sutton, 1992), p. 235.

${ }^{35}$ Peter France, Politeness and its Discontents: Problems in French Classical Culture (Cambridge: Cambridge UP, 1992), pp. 64-65.

${ }^{36}$ Skrbiš and Woodward, Cosmopolitanism, pp. 2, 115.

${ }^{37}$ As he revealed in a letter to John Hall-Stevenson of 19 October 1762, the 'ground work' of Sterne's own disillusionment with France was 'more to the eternal platitude of the French characters - little variety, no originality in it at all — than to any other cause - for they are very civil—but civility itself, in that uniform, wearies and bodders one to death' (Letters, VII, 294). ${ }^{38}$ For some critics, this movement from pastoral revelation back to the urbane environment of the final chapter can only be regarded as a regrettable 'relapse'. See for instance John A. Dussinger, 'Yorick and the "Eternal Fountain of our Feelings"', in Psychology and Literature in the Eighteenth Century, ed. Christopher Fox (New York: AMS Press, 1987), pp. 259-76 (p. 271).

${ }^{39}$ Turner, British Travel Writers, p. 17. Turner aligns both Sterne and Smollett with the formation of a 'manly, middle-class, British sensibility' (p. 85).

${ }^{40}$ The Life and Opinions of Tristram Shandy, Gentleman: The Text, ed. Melvyn New and Joan New, vols. 1-2 of The Florida Edition of the Works of Laurence Sterne (Gainesville: University Presses of Florida, 1978), I.xix.61. In some respects, the categories of philosophical thinking are themselves treated with comic scepticism in the Journey, as for instance in the preface when Yorick reflects, somewhat ponderously, on 'the efficient as well as the final causes of travelling' (p. 13).

${ }^{41}$ Where Nussbaum, in her call for cosmopolitan education, promoted the cosmopolitan as 'the person whose allegiance is to the worldwide community of human beings', other contributors to this debate highlighted the 'utopian' and 'abstract' nature of cosmopolitanism itself. See Martha C. Nussbaum et al, For Love of Country?, ed. Joshua Cohen (Boston: Beacon Press, 1996; 2002), pp. 4, 76, 82.

${ }^{42}$ Nussbaum et al, For Love of Country?, p. 22. As Appiah himself states in Cosmopolitanism, there is 'a sense in which cosmopolitanism is the name not of the solution but of the challenge' (p. xiii).

${ }^{43}$ Margaret C. Jacob, ‘The Cosmopolitan as a Lived Category', Daedalus, 137 (2008), 18-25;

Bruce Robbins, 'Introduction Part I: Actually Existing Cosmopolitanism', in Cosmopolitics:

Thinking and Feeling Beyond the Nation, ed. Pheng Cheah and Bruce Robbins (Minneapolis:

University of Minnesota Pres, 1998), p. 1.

${ }^{44}$ Forman-Barzilai, Adam Smith and the Circles of Sympathy, p. 4. 